\title{
IZOBRAŽEVANJE ZA LOKALNO TRAJNOSTNO OSKRBO S HRANO
}

dr. Tatjana Resnik Planinc, Mojca Ilc

Oddelek za geografijo, Filozofska fakulteta Univerze v Ljubljani, Aškerčeva 2, SI-I000 Ljubljana

e-mail: tatjana.resnik-planinc@guest.arnes.si; mojcailc@yahoo.com

Izvirni znanstveni članek

COBISS 1.01

\section{Izvleček}

Prispevek se ukvarja $\mathrm{z}$ lokalno trajnostno oskrbo s hrano z vidika izobraževanja in ozaveščanja otrok ter mladostnikov. Avtorici prek analize obstoječega stanja podata predloge za vključevanje tematike v pouk geografije na osnovnošolskem in srednješolskem nivoju. Prepričani sta, da je umestitev izbrane teme v obvezni izobraževalni program svojstven dokaz njenega pomena za vsakdanje življenje in razvoj posameznika in družbe ter zagotovilo, da bodo sporočila dosegla najširši krog prebivalstva.

Ključne besede: geografija, izobraževanje, lokalna trajnostna oskrba s hrano, učni načrt

\section{EDUCATION FOR LOCAL SUSTAINABLE FOOD SUPPLY}

\begin{abstract}
This paper looks at local sustainable food supplies from the aspect of education and youth awareness. Through analysis of the present circumstances, the authors offer suggestions of how to implement the chosen theme into a geography lesson within primary and secondary schools. They are convinced the implementation of a chosen theme into a compulsory educational programme proves its importance in everyday life, in the development of an individual and for society as a whole, thereby offering us an assurance that the main ideas will reach the majority of the population.
\end{abstract}

Key words: geography, education, local sustainable food supply, syllabus 


\section{UVOD}

Lokalna trajnostna oskrba s hrano je eden strateških ciljev prehranske politike, opredeljen tudi v Resoluciji o nacionalnem programu prehranske politike 2005-2010. Čeprav se vsi zavedamo njenega pomena, pa teorija le počasi prehaja $\mathrm{v}$ prakso, kar posledično pomeni, da je tudi na področju izobraževanja in ozaveščanja otrok ter mladostnikov potrebno storiti še veliko.

Ker moramo vsi jesti, je hrana sama po sebi odlično izhodišče za izobraževanje, kajti pomembno je, kaj jemo. Naša izbira hrane vpliva na naše zdravje, kakovost okolja, delovna mesta v naših skupnostih, na kulturo in raznolikost naše družbe. Ni dovolj, da le poskrbimo za vzpostavitev ponudbe zdrave, po možnosti lokalno pridelane hrane v gostinskih in turističnih obratih ter $\mathrm{v}$ javnih zavodih, med katere spadajo tudi vrtci, šole in ostale izobraževalne institucije, vključno z dijaškimi in študentskimi domovi. Tudi obveščanje samo po sebi ni dovolj, saj predvsem mladi v poplavi vsakodnevnih informacij tudi tiste, ki so zanje pomembne, pogosto preslišijo ali pa jim ne pripisujejo ustreznega pomena. Od ljudi pričakujemo, da bodo spremenili svoj življenjski slog in način prehranjevanja. Že za odraslega človeka je to včasih izjemno težko, kaj šele za otroka in mladostnika. Spremembe se morajo začeti najprej v njihovih osnovnih, matičnih celicah - družinah. Če otrok oziroma mladostnik čuti in razume, da gre za nekaj dobrega, za nekaj, kar podpira njegova družina, šola in širša družba, bo verjetno pripravljen sprejeti spremembe prej, kot če dogajanje dojema le na formalni, teoretični ravni v šoli.

Onesnaženost zraka, aditivi, antibiotiki, dobrobit živali, biodiverziteta, klimatske spremembe, kloniranje, pesticidi, bolezen norih krav, skrb za zdravje, genetski inženiring, ekološko pridelana hrana, revščina in lakota itn., je le nekaj tem, s katerimi so soočeni otroci in mladina. Če želimo, da razumejo njihovo kompleksnost, pomen in vpliv, moramo biti pri načrtovanju vzgojno-izobraževalnega dela izjemno strokovni, natančni in dosledni. Obenem se mora javnost zavedati, da so učitelji zavezani učnim načrtom, v katerih (tudi prenovljenih) vsebine, povezane s trajnostno lokalno oskrbo s hrano, sploh niso vključene ali pa niso vključene v zadostni meri. Gotovo je težko govoriti o prioriteti enega samega šolskega predmeta, ki bi lahko pokril celostnost pereče problematike, kajti veliko predmetov se je tako ali drugače dotika. Pri trajnostni lokalni oskrbi s hrano pa je ravno celovitost in celostnost dojemanja ključnega pomena, zato je tako želeno in priporočano medpredmetno povezovanje gotovo eden izmed načinov za dosego le tega.

Trenutno veljavni učni načrti za geografijo v nobenem izmed učnih ciljev ne govorijo konkretno o lokalni trajnostni oskrbi s hrano, a kljub temu nekoliko ohlapnejše zapisani cilji, predvsem pa splošni učni cilji, učitelju dopuščajo možnost obravnave te kompleksne vsebine. Zavedati se moramo, da je predpogoj za obravnavo aktualnih vsebin, ki še niso vključene v učne načrte, učiteljeva lastna ozaveščenost in dobro poznavanje problematike.

\section{TRAJNOSTNI RAZVOJ IN LOKALNA OSKRBA S HRANO}

Trajnostni razvoj je način družbenega in gospodarskega razvoja, ki je usmerjen v izboljšanje kakovosti življenja sedanjih generacij, obenem pa teži k ohranjanju in zagotavljanju 
najboljših možnosti za prihodnje generacije. Koncept trajnostnega razvoja vključuje tako skrb za ohranjanje okolja, trajnostno (sonaravno) rabo naravnih virov, povečanje ekonomske in socialne blaginje, pri čemer upošteva prihodnje generacije, kot tudi trajnostno kmetijstvo in industrijo in ne nazadnje tudi trajnostni razvoj podeželja (Buzeti 2005, 5). Buzetijeva definira trajnostno kmetijstvo kot »način pridelave živil/hrane, ki zagotavlja kakovostne pridelke in hkrati ohranja oziroma izboljšuje kakovost ter preprečuje erozijo tal, ne ustvarja škodljivih učinkov pesticidov na okolje, ohranja biološko pestrost ekosistemov, ustvarja želene donose na kmetijskih površinah, ohranja uravnoteženo energijsko bilanco, ne onesnažuje podtalnice, ohranja in veča socialni in človeški kapital na podeželju ter krepi razvoj lokalnih gospodarstev« (Buzeti 2005, 5). Posledično predstavlja lokalna trajnostna oskrba s hrano lokalno pridelavo, predelavo in distribucijo trajnostno proizvedene hrane, ki je fizično in cenovno dostopna lokalnemu prebivalstvu in nato porabljena na lokalnih trgih, za kar se je uveljavil pregovor 'od njive do krožnika v lokalnem okolju' (Buzeti 2005, 5). Med tem pa Nacionalni program prehranske politike za obdobje 2005-2010 prej omenjeno definicijo še nekoliko nadgradi in pojasni, da pomeni lokalna trajnostna oskrba s hrano »pridelavo, predelavo in porabo na lokalni ravni. Cilj je povečati porabo kakovostnih, lokalno trajnostno pridelanih in zdravju koristnih živil/hrane, okrepiti skrb za okolje in pitno vodo, spodbuditi razvoj lokalnega gospodarstva in podeželja, vzpostaviti dobro kmetijsko prakso ter okrepiti možnosti za samooskrbo ob nestabilnih razmerah na svetovnih trgih z živili/hrano« (Nacionalni program... 2005, 34).

\section{Slika 1: Sistem hrane}

Figure 1: Food system

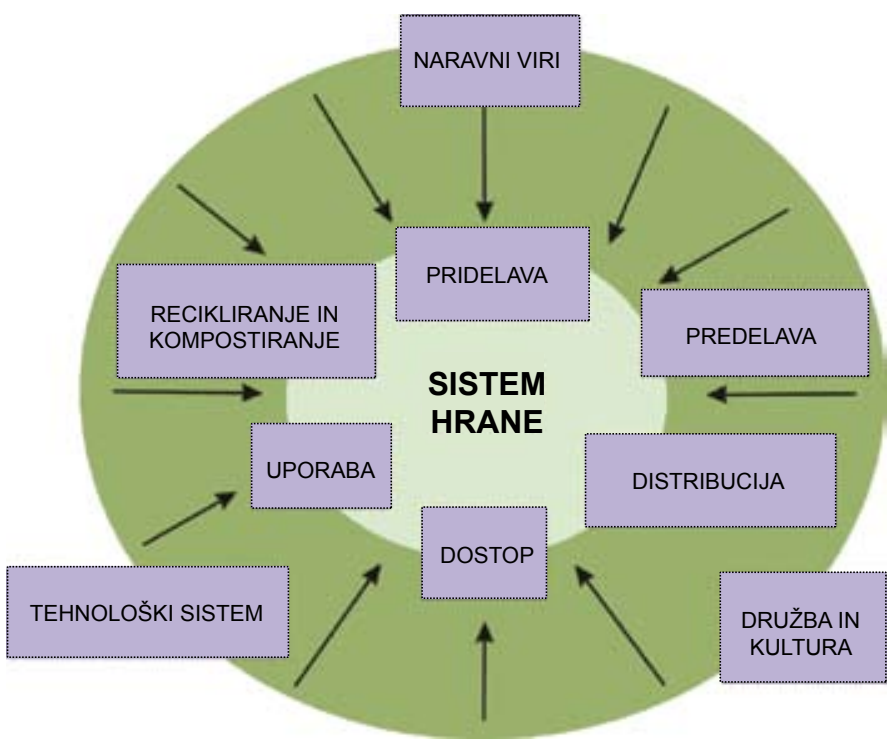

Vir/Source: Dahlberg 1994 
Ob dejstvu, da v zadnjem desetletju narašča zavedanje o pomenu lokalno pridelane hrane, ne moremo mimo same opredelitve lokalnosti. Kajti čeprav gre za hrano, ki jo pridelajo, predelajo in distribuirajo na lokalni ravni, vseeno obstaja več opredelitev lokalnosti. Dahlberg (1994) govori o družbenem, gospodarskem in okoljskem vidiku pridelave, predelave, distribucije, dostopa, uporabe in recikliranja ter kompostiranja odpadkov (slika 1). Drugi zopet pojmujejo kot lokalno pridelano hrano, ki je zrasla $\mathrm{v}$ radiu $64,4 \mathrm{~km}$ od mesta pridelave (Nash 2003; citirano po Thomson in sod. 2006). Za Smitha (2003; citirano po Thomson in sod. 2006) pomeni lokalno dostavo še istega dne, ko je bil pridelek pobran, a smatra kot ustrezno razdaljo do $161 \mathrm{~km}$. Isensee (2003; citirano po Thomson in sod. 2006) pa na drugi strani ponuja bolj celovit opis lokalnega, saj pravi, da je razdalja do 1,6 km soseščina, od 1,6 do 16,1 km mesto, 17,7 do 40,2 km lokalno območje ter 41,8 do 161 oziroma 241,4 km regija.

Veliko raziskovalcev je dokumentiralo prednosti lokalno pridelane hrane (Dahlberg 1994; DeLind 1994; Gordon 2003). Te prednosti so kategorizirane kot družbene (poznati izvor hrane, način pridelave, interakcijo med enako mislečimi porabniki), gospodarske (podpora lokalnemu gospodarstvu, manjši transportni stroški, porast zaposlovanja na lokalnem območju), prednosti za zdravje (izboljšana varnost hrane in manjše tveganje za bioterorizem) ter okoljske (ohranjanje biološke diverzitete in zmanjšanje uporabe pesticidov/kemikalij).

V Sloveniji navaja Nacionalni program prehranske politike (2005) kot ključne priložnosti lokalne trajnostne oskrbe s hrano sledeče:

- večji delež kakovostnih, zdravju koristnih in lokalno značilnih živil/hrane v prehrani prebivalstva;

- večanje gospodarske moči in večja možnost za zaposlovanje na lokalni ravni;

- uveljavljanje podeželja in podeželskega turizma s pomočjo lokalno pridelane hrane na tradicionalen način;

- Vzpostavitev novih tržnih priložnosti za lokalnega kmeta ter večanje dodane vrednosti kmetijskih pridelkov in proizvodov;

- oživitev mestnih jeder s ponudbo lokalno pridelane hrane na mestnih tržnicah ter zbližanje in boljše povezovanje mestnih in podeželskih občin;

- zadovoljitev vse večjih potreb potrošnikov po lokalno pridelani hrani in posebnih kmetijskih proizvodih;

- prispevek k povečanju socialnega in človeškega kapitala na podeželju ter $\mathrm{h}$ krepitvi in razvoju lokalnih gospodarstev, kar bo pripomoglo k ohranitvi poseljenosti slovenskega podeželja in nacionalnih dobrin;

- pozitivni prispevek k varovanju in ohranjanju okolja in kakovosti tal, zmanjšanju škodljivih učinkov pesticidov na okolje, prispevek k ohranjanju pestrosti ekosistemov in trajnostni rabi energentov, zaščita podtalnice (Nacionalni program... 2005, 34).

Posledično lahko cilje lokalne trajnostne oskrbe s hrano, med katere spadajo izboljšanje prehranskih navad prebivalstva, z upoštevanjem sezonskosti, svežosti in raznovrstnosti lokalne ponudbe, razvoj lokalne ekonomije in izboljšanje socialno-ekonomskega statusa lokalnih pridelovalcev ter varovanje okolja (manj transporta in odpadkov, zagotoviti večjo kakovost in zdravstveno ustreznost živil) ovrednotimo kot smiselne in realne. Na eni strani dobijo ponudniki lokalno trajnostno pridelane hrane priložnost za razvoj lokalnega trga, 
znižanje stroškov logistike na račun krajših transportnih poti in v stabilnosti povpraševanja, na drugi strani pa vidimo pomen lokalne trajnostne oskrbe za javne zavode zlasti v treh točkah (Buzeti 2005, 5-6):

\section{Zagotavljanje živil, pridelanih na sonaravni/trajnostni način.}

Na tem mestuje treba poudariti, da pomeni integrirana pridelava »uravnoteženo uporabo agrotehničnih ukrepovob skladnem upoštevanju gospodarskih, ekoloških in toksikoloških dejavnikov« (Buzeti 2005, 6). Pravila integrirane pridelave določajo pravilniki o integrirani pridelavi sadja, integrirani pridelavi zelenjave, integrirani pridelavi grozdja in vina (UL RS 63/02) ter integrirani pridelavi poljščin (UL RS 31/01; Buzeti 2005, 6) Pojasniti pa moramo tudi, da je ekološka pridelava »način trajnostnega kmetovanja, ki $v$ pridelavi hrane temelji na ravnovesju tla - rastline -živali-človek in krogotoku hranil v njem. Prepovedana je uporaba lahkotopnih mineralnih gnojil, sintetičnih farmacevtskih sredstev in gensko spremenjenih organizmov. Pravila ekološkega kmetovanja določa Pravilnik o ekološki pridelavi in predelavi kmetijskih pridelkov oziroma živil (UL RS 31/ 01)«(Buzeti 2005, 6).

\section{Tesnejši stik z okoljem.}

3. Vzgojno-izobraževalni dejavnik in vzgoja za izbiro zdrave, lokalno pridelane hrane.

$V$ tej točki vidimo možnost vključevanja vsebin lokalne trajnostne oskrbe s hrano pri pouku različnih predmetov, tudi geografije.

Svetovna zdravstvena organizacija postavlja v svojih dokumentih, ki opredeljujejo področje delovanja prehranske politike, tri temeljne stebre, ki so pomembni za zagotavljanje varnega in zdravega prehranjevanja.

Preglednica 1: Varno in zdravo prehranjevanje

Table 1: Safe and healthy eating

\begin{tabular}{|l|l|l|}
\hline \multicolumn{2}{|c|}{ VARNO IN ZDRAVO PREHRANJEVANJE } \\
\hline Varna živila/hrana. & $\begin{array}{l}\text { Uravnoteženo in varovalno } \\
\text { prehranjevanje. }\end{array}$ & $\begin{array}{l}\text { Zagotavljanje trajnostne oskrbe } \\
\text { živili. }\end{array}$ \\
$\begin{array}{l}\text { Preprečevanje biološkega, } \\
\text { kemičnega in fizikalnega } \\
\text { onesnaževanja hrane oziroma } \\
\text { živil na vseh stopnjah živilske } \\
\text { verige: pridelave, predelave in } \\
\text { trgovine z živili ter priprave/ } \\
\text { ponudbe hrane. }\end{array}$ & $\begin{array}{l}\text { Zagotavljanje optimalnega } \\
\text { zdravja s pomočjo zdravih } \\
\text { prehranjevalnih navad in } \\
\text { zdravega prehranjevanja. }\end{array}$ & $\begin{array}{l}\text { Zagotavljanje dostopnosti do } \\
\text { kakovostne in zdravju prijazne } \\
\text { hrane, ki upošteva kulturno } \\
\text { okolje, specifične načine } \\
\text { prehranjevanja prebivalcev ter } \\
\text { uresničuje razvijanje trajnostnih } \\
\text { kmetijskih in okoljevarstvenih } \\
\text { politik. }\end{array}$ \\
\hline
\end{tabular}

Vir/Source: Buzeti 2005, 1 
Ozaveščanje potrošnikov in pozitivna podoba sta gotovo temeljnega pomena za povečano porabo lokalnih pridelkov in izdelkov. Mlekomati, stojnice z lokalnimi pridelki, slovensko sadje (in zelenjava) v prodajnih avtomatih, nižja cena slovenskega sadja in zelenjave v trgovinah, dajanje prednosti lokalni hrani pri javnem naročanju v javnih ustanovah itd. je le nekaj možnosti, ki bi lahko povečale porabo. Tako velja omeniti dobro prakso, ki se trenutno odvija v Sloveniji. Gre za Shemo šolskega sadja, ki predstavlja pomembno priložnost za državo, saj bomo s promocijo in vključevanjem lokalnega kmeta prispevali k porabi slovenskega sadja in zelenjave.

V povezavi z že omenjenimi priporočili in v navezavi z dobro šolsko prakso pa so ključnega pomena prehranjevalne navade ljudi, ki pomenijo načine prehranjevanja posameznika, skupine ali družbe kot celote in so značilne za določen kulturni kontekst. Vključujejo izbor in količino živil, delež posameznih živil v prehrani, način priprave hrane in pogostost ter razporejenost uživanja posameznih obrokov hrane preko dneva. Na prehranjevalne navade vplivajo socialne, ekonomske, etnične in kulturne danosti okolja, pa tudi izobraženost ljudi ter dostopnost in ne nazadnje tudi cena hrane. Pravilne prehranjevalne navade so tiste, ki omogočajo, da je prehrana posameznika, skupine ali družbe kot celote ob upoštevanju vseh prej omenjenih vplivov skladna s priporočili za zdravo prehrano (Gabrijelčič Blenkuš in sod. 2009, 17).

Različne raziskave o načinu prehranjevanja v Sloveniji so pokazale, da je prehrana slovenskega prebivalstva nezdrava. Število dnevnih obrokov in ritem prehranjevanja sta neustrezna, energijska vrednost posameznega obroka je previsoka, zaužijemo preveč maščob, posebno nasičenih, ki pomembno vplivajo na bolezni srca in ožilja. V naši prehrani je tudi premalo sadja, predvsem pa tudi premalo zelenjave. Prav gotovo so zaskrbljujoči podatki raziskave $Z$ zdravjem povezan življenjski slog, po kateri se v Sloveniji zdravo in pretežno zdravo prehranjuje zgolj 23 \% odraslega prebivalstva. Pri tem so posebej ogroženi moški, ljudje iz nižjih družbenih slojev, osebe z nižjo stopnjo izobrazbe, aktivno zaposleni, prebivalci vaškega bivalnega okolja ter populacija v starosti med 25 in 49 let (Gabrijelčič Blenkuš in sod. 2009, 17-18).

Prva raziskava, narejena med prebivalstvom Slovenije, z naslovom Prehrambene navade odraslih Slovencev $z$ vidika varovanja zdravja je pokazala, da je naša prehrana nezdrava tako po sestavi kot tudi po načinu priprave hrane in režimu prehranjevanja. Izpostavila je, da pojemo:

- premalo sadja (povprečen Slovenec poje le en sadež dnevno);

- relativno premalo sestavljenih ogljikovih hidratov (39\% dnevnega energijskega vnosa namesto $55-75 \%$ );

- premalo vlaknin (20 g namesto 27 do $40 \mathrm{~g})$;

- preveč maščob (44 \% dnevnega energijskega vnosa namesto do $30 \%$ );

- preveč nasičenih maščob (15\% namesto do $10 \%$ dnevnega energijskega vnosa);

- preveč enostavnih ogljikovih hidratov (sladkarij, sladkih pijač).

Poleg tega hrano preveč solimo (26 \% ljudi dosoljuje hrano pri mizi), jemo preveč kalorično hrano in le polovica Slovencev redno zajtrkuje (Gabrijelčič Blenkuš in sod. 2009, 18). 
Vsi navedeni podatki otroku in mladostniku ne povedo veliko. Čeprav se že v vrtcu in kasneje v šoli srečajo s prehrambeno piramido, jim ta sama po sebi ne pove dovolj. Ravno tako jih samo poznavanje ogljikovih hidratov, maščob in beljakovin, s katerimi se seznanijo pri biologiji, še ne bo prepričalo, da bi upoštevali priporočila zdrave prehrane. Šele celosten pristop, ki nujno vključuje medpredmetno sodelovanje na šolski ravni, nadgrajen s spremembami v lastni družini, jih bo pripeljal na pot, ki jo priporočamo.

\section{POUK GEOGRAFIJE IN LOKALNA TRAJNOSTNA OSKRBA S HRANO}

Načelo trajnostne lokalne oskrbe s hrano terja od nas kot posameznikov in kot dela družbe, da razmišljamo o svojem načinu življenja, o posledicah svojih dejanj z vidika razvoja, družbenega napredka in stanja okolja ter da na osnovi tega oblikujemo ustrezne rešitve. Ne razmišljajmo zgolj o ustvarjanju kakovostnejšega življenja za nas, ampak tudi o možnostih in priložnostih prihajajočih generacij.

Uvajanje novosti v šolo zagotovo sodi med zelo zahtevne naloge. Izobraževanje o trajnostnih razsežnostih življenja in razvoja se mora preusmeriti od podatkov k procesom, razmerjem in odnosom, kar zahteva spoznavno in projektno učenje ter medpredmetno povezovanje. Metodološko se ta pričakovanja ujemajo z razvojem poučevanja, kar je temi gotovo v prid.

Tematika sama po sebi tudi sicer ponuja veliko možnosti za praktično pridobivanje znanja, obenem pa lahko naloge v vsaki šoli ali skupini pridobijo povsem samosvoje razsežnosti. Vsako nalogo namreč vedno oblikujejo prek nje povezani ljudje, prostor in problemi. Učitelji so tako sicer postavljeni pred težko nalogo, ki pa gotovo tudi zanje pomeni pridobivanje novih, drugačnih izkušenj.

Teoretično in metodološko dodelano izobraževanje $\mathrm{z}$ vidika lokalne trajnostne oskrbe $\mathrm{s}$ hrano bi moralo enako kot izobraževanje z vidika celostnega trajnostnega razvoja po priporočilih UNECE iz leta 2004 vključevati akcijsko učenje, kritično mišljenje, dinamiko kot kakovost, interdisciplinaren pristop, multidisciplinaren pristop, problemski pristop, procesno orientiran pristop, reševanje problemov, projektno delo ter učenje v naravi, na prostem, $\mathrm{v}$ pokrajini (izkustveno učenje), pri čemer naj bi učni proces prevzel obliko kompleksne, strukturirane 'delavnice'.

Ob dejstvu, da je učitelj zavezan učnemu načrtu, ne moremo mimo ključnega pomena le-tega za vključevanje aktualnih vsebin v pouk geografije. Trenutno veljavni učni načrti za geografijo v nobenem izmed učnih ciljev ne govorijo konkretno o lokalni trajnostni oskrbi s hrano, vendar posamezni, nekoliko ohlapnejše zapisani cilji, predvsem pa splošni učni cilji učitelju dopuščajo možnost obravnave te kompleksne vsebine. V nadaljevanju podajamo celovit pregled učnih ciljev v geografskih učnih načrtih, ki se vežejo na trajnostno lokalno oskrbo z živili, ter pregled geografskih učbenikov in vključenosti vsebin, ki se lahko povežejo $\mathrm{z}$ lokalno trajnostno oskrbo s hrano. 
Preglednica 2: Učni cilji v geografskih učnih načrtih, ki se vežejo na trajnostno lokalno oskrbo $z$ živili

Table 2: Learning objectives in geographical syllabi that bind to local sustainable food supply

\begin{tabular}{|c|c|}
\hline \multicolumn{2}{|l|}{ OSNOVNA ŠOLA } \\
\hline SPLOŠNI CILJI & $\begin{array}{l}\text { Učenci pri pouku geografije razvijajo vrednote, ki prispevajo k: } \\
\text { - skrbi za kvaliteto in načrtovanje uravnotežene rabe okolja ter skrbi za } \\
\text { življenje prihodnjih generacij (trajnostni razvoj); } \\
\text { - razumevanju pomena odnosov in vrednot pri odločanju o posegih v prostor; } \\
\text { - skrbi za ohranjanje zdravja okolja in lastnega zdravja. }\end{array}$ \\
\hline 7. RAZRED & $\begin{array}{l}\text { Južna Evropa } \\
\text { - Učenec opiše načine, s katerimi človek izboljšuje naravne pogoje za } \\
\text { kmetijstvo. }\end{array}$ \\
\hline 8. RAZRED & - Učenec razume občutljivo povezanost med človekom in naravo. \\
\hline 9. RAZRED: & $\begin{array}{l}\text { Gospodarstvo } \\
\text { - Učenec ovrednoti pomen kmetijstva in sklepa o možnosti kmetijske } \\
\text { dejavnosti v različnih predelih Slovenije. }\end{array}$ \\
\hline $\begin{array}{l}\text { PRIČAKOVANI } \\
\text { REZULTATI DRUGEGA } \\
\text { TRILETJA: }\end{array}$ & $\begin{array}{l}\text { - Učenec razume, da sta človek in proizvodnja hrane odvisna od narave; } \\
\text { - Učenec pozna pomen racionalnega ravnanja z naravnimi viri. }\end{array}$ \\
\hline \multicolumn{2}{|l|}{ SPLOŠNA GIMNAZIJA } \\
\hline 1. LETNIK & $\begin{array}{l}\text { Kmetijstvo } \\
\text { - Dijaki spoznajo različne oblike kmetijstva z vidika razvoja in intenzivnosti } \\
\text { ter razložijo vzroke za njihov nastanek; } \\
\text { - dijaki vrednotijo rabo tal na izbranih primerih; } \\
\text { - dijaki si pridobijo pozitiven odnos do pomena kmetijstva za oskrbo s hrano in } \\
\text { surovinami ter ohranjanje kulturne pokrajine; } \\
\text { - dijaki opazujejo pokrajino in iz nje razberejo prvine, ki so funkcijsko } \\
\text { povezane s kmetijstvom; } \\
\text { - dijaki raziskujejo okoljske probleme intenzivnega kmetijstva in okoljske } \\
\text { probleme z vidika vpliva narave ter negospodarnega ravnanja z njo; } \\
\text { - dijaki ob izbranih primerih ovrednotijo pomen kmetijstva za oskrbo ljudi s } \\
\text { hrano in surovinami. }\end{array}$ \\
\hline \multicolumn{2}{|c|}{ STROKOVNA GIMNAZIJA } \\
\hline 1. LETNIK & $\begin{array}{l}\text { Človek in pokrajina } \\
\text { Sodobni svet in geografski procesi v njem } \\
\text { - Dijaki razlagajo propadanje tradicionalnih in nastajanje modernih oblik } \\
\text { kmetijstva in industrije; } \\
\text { - dijaki pojasnjujejo problem pomanjkanja hrane. }\end{array}$ \\
\hline
\end{tabular}

Vira/Sources: Učni načrti za geografijo 2003; 2008 
Preglednica 3: Geografski učbeniki in vključenost vsebin, ki se lahko povežejo z lokalno trajnostno oskrbo z živili

Table 3: Geography textbooks and inclusion of contents that can be connected with local sustainable food supply

\begin{tabular}{|c|c|}
\hline \multicolumn{2}{|l|}{ OSNOVNA ŠOLA } \\
\hline $\begin{array}{l}\text { Geografija 9, } \\
\text { Mladinska knjiga, } \\
91 \text { str. Ljubljana } 2006 .\end{array}$ & $\begin{array}{l}\text { Učna tema: Kmetijstvo } \\
\text { - Razlaga pojmov: intenzivno, ekstenzivno kmetijstvo, hektarski donos, } \\
\text { melioracija, specializacija, biokmetijstvo (predlog: lokalna trajnostna oskrba } \\
\text { s hrano); } \\
\text { - Str. 25: shema Hipermarket Mercator (predlog: narediti shemo lokalne } \\
\text { trgovine in popis lokalnih (trajnostnih) živil; sestaviti predlog nadomestitve } \\
\text { današnjih živil z lokalnimi). }\end{array}$ \\
\hline $\begin{array}{l}\text { Geografija Slovenije, } \\
\text { DZS, } 112 \text { str. } \\
\text { Ljubljana } 2003 .\end{array}$ & $\begin{array}{l}\text { Učna tema: Od agrarne do industrijske pokrajine } \\
\text { - Razlaga pojmov: intenzivno, ekstenzivno kmetijstvo, vinogradništvo, } \\
\text { sadjarstvo, hektarski donosi, ogozdovanje, biokmetijstvo, melioracija } \\
\text { (predlog: lokalna trajnostna oskrba s hrano); } \\
\text { - Nadomestiti kakšno fotografijo ali dodati novo (lokalna trajnostna oskrba } \\
\text { s hrano). }\end{array}$ \\
\hline $\begin{array}{l}\text { Živim v Sloveniji. } \\
\text { Modrijan, } 151 \text { str. } \\
\text { Ljubljana } 2008 .\end{array}$ & $\begin{array}{l}\text { Učna tema: Kmetijstvo } \\
\text { Razlaga pojmov: naravni dejavniki, hribovsko kmetijstvo, melioracije, } \\
\text { razdrobljenost, prostorska razporeditev parcel, komasacije, ozelenjevanje, } \\
\text { ogozdovanje, ekstenzivno, intenzivno kmetijstvo, specializirano kmetijstvo, } \\
\text { tržno kmetijstvo, samooskrbno, sonaravno kmetijstvo, biokmetijstvo, vrtnine, } \\
\text { sadjarstvo, živinoreja (vrste) (predlog: lokalna trajnostna oskrba s hrano). }\end{array}$ \\
\hline \multicolumn{2}{|l|}{ SREDNJA ŠOLA } \\
\hline $\begin{array}{l}\text { Obča geografija za } \\
\text { 1. letnik gimnazij. } \\
\text { Mladinska knjiga, } \\
152 \text { str. Ljubljana } 2001\end{array}$ & $\begin{array}{l}\text { Učna tema: Kmetijstvo } \\
\text { Razlaga pojmov: poljedelstvo, živinoreja, samooskrbno kmetijstvo, ekstenzivno, } \\
\text { tržno, intenzivno, specializirano, monokulturno kmetijstvo, plantaže, } \\
\text { polikulturno kmetijstvo, kmetijska območja, agrarna prenaseljenost, vplivi } \\
\text { kmetovanja na okolje (predlog: lokalna trajnostna oskrba s hrano). }\end{array}$ \\
\hline $\begin{array}{l}\text { Obča geografija za } \\
\text { 1. letnik gimnazij. } \\
\text { Modrijan, } 183 \text { str. } \\
\text { Ljubljana } 2002 .\end{array}$ & $\begin{array}{l}\text { Učna tema: Kmetijstvo } \\
\text { Razlaga pojmov: agrarna prenaseljenost, deagrarizacija, kmetijske panoge, } \\
\text { tradicionalno kmetijstvo, sodobno kmetijstvo, agrotehnična sredstva, } \\
\text { ročno, strojno obdelovanje, ekstenzivno, intenzivno, samooskrbno, tržno, } \\
\text { monokulturno, polikulturno, specializirano kmetijstvo, erozija prsti, kemizacija } \\
\text { kmetijstva, umetna gnojila, zaščitna sredstva, alternativno ali biološko } \\
\text { kmetijstvo, umetno namakanje (predlog: lokalna trajnostna oskrba s hrano). }\end{array}$ \\
\hline $\begin{array}{l}\text { Geografija za srednje } \\
\text { šole. DZS, } 285 \text { str. } \\
\text { Ljubljana } 2004 \text {. }\end{array}$ & $\begin{array}{l}\text { Učna tema: Kmetijstvo } \\
\text { Razlaga pojmov: poljedelstvo, živinoreja, vinogradništvo, sadjarstvo, } \\
\text { vrtnarstvo, pogoji za kmetijstvo, rastlinski pasovi, ekstenzivno, intenzivno } \\
\text { kmetijstvo, samooskrbno, tržno, plantažno, monokulturno, polikulturno, } \\
\text { specializirano kmetijstvo, nomadska živinoreja, polnomadizem, živinoreja } \\
\text { (vrste), parcelna razdrobljenost, izvoznice hrane, glavni kmetijski pridelki, } \\
\text { deagrarizacija, kmetijska politika, ozelenjevanje, ogozdovanje, litoralizacija, } \\
\text { degradacija okolja, erozija kmetijskih zemljišč, namakalne površine, problemi } \\
\text { kmetijstva, problemi tržnega kmetijstva, vključevanje v EU (predlog: lokalna } \\
\text { trajnostna oskrba s hrano). }\end{array}$ \\
\hline
\end{tabular}




\begin{tabular}{|l|l|}
\hline & $\begin{array}{l}\text { Učna tema: Kmetijstvo } \\
\text { Razvojne faze slovenskega gospodarstva, mešane kmetije, skupna evropska } \\
\text { kmetijska politika, deagrarizacija, depopulacija, družinske kmetije, }\end{array}$ \\
$\begin{array}{l}\text { Slovenija 1. } \\
\text { Modrijan, } 120 \text { str. } \\
\text { Ljubljana 2008. }\end{array}$ & $\begin{array}{l}\text { kzelijska podjetja in zadruge, raba tal, zemljiška kategorija, pogozdovanje, } \\
\text { razdrobljenost, komasacije, specializacija, vodilne kulture, živinoreja, } \\
\text { vinogradništvo, tipi demografskih območij, urbanizacija, klasična agrarna } \\
\text { pokrajina, prehodna območja, podjetništvo, ekološko kmetovanje, gozdarstvo } \\
\text { (predlog: lokalna trajnostna oskrba s hrano). }\end{array}$ \\
\hline
\end{tabular}

Viri/Sources: Geografski učbeniki 2001, 2003, 2004, 2006, 2008

Pregled potrjuje zelo skromno zastopanost vsebin, povezanih z lokalno trajnostno oskrbo s hrano, v celotni vertikali osnovnošolskega in srednješolskega geografskega izobraževanja. Ob zavedanju, da zahteva vsaka, še tako majhna sprememba učnega načrta izjemno veliko truda in časa, pri čemer gre za celovit proces, ki ni v domeni posamezne stroke, ampak celotnega družbenega konsenza na ravni Ministrstva za šolstvo in šport, postane jasno dejstvo, da so za zdaj te vsebine in njihovo vključevanje v pouk geografije (in drugih predmetov) skorajda povsem $\mathrm{v}$ rokah učiteljev.

\section{PREDLOGI VKLJUČEVANJA VSEBIN NA TEMO LOKALNE TRAJNOSTNE OSKRBE S HRANO V POUK GEOGRAFIJE}

V nadaljevanju podajamo konkretne predloge vključevanja vsebin, povezanih z lokalno trajnostno oskrbo hrano, v pouk geografije.

\section{Predlogi vključevanja vsebin}

Preglednica 4: Predlogi vključevanja vsebin, povezanih z lokalno trajnostno oskrbo s hrano.

Table 4: Proposed inclusion of contents, related to local sustainable food supply.

\begin{tabular}{|c|c|}
\hline Šola & Predlagane vsebine \\
\hline Osnovna šola & $\begin{array}{l}\text { EKO DAN (npr. na Dan Zemlje, 22. 4.) } \\
\text { 1. Sodeluje vsa šola: } \\
\text { - poizkusi: domače in kupljeno grozdje - spremljamo hitrost gnitja, lahko uporabimo } \\
\text { različno sadje; } \\
\text { - pojdi v trgovino in izpiši za vsako sadje in zelenjavo, od kod prihaja; } \\
\text { - kemija: analiza sladkorja v sadju; } \\
\text { - fizika: Newton. } \\
\text { 2. Gospodinjstvo (skozi vse leto): } \\
\text { - obisk ekokmetije, peka kruha iz domače moke; } \\
\text { - stiskanje sadnega soka, izdelava jabolčnega kisa; } \\
\text { - jeseni kuhanje marmelade iz domačih sliv. } \\
\text { 3. Prepoz,navanje in poz,navanje znakov za eko hrano } \\
\text { 4. Branje deklaracij na hranilih in hrani } \\
\text { 5. Izdelava avtomata za zdravo hrano (ne le kavomat ...) } \\
\text { 6. Odnos do zdrave hrane, odnos do lokalne hrane }\end{array}$ \\
\hline
\end{tabular}




\begin{tabular}{|c|c|}
\hline Osnovna šola & $\begin{array}{l}\text { 7. Slovenski jezik: } \\
\text { - branje literature Pehar suhih hrušk, slovenske pesmi o kruhu in vinu } \\
\text { 8. Naravoslovni dan: } \\
\text { - obisk ekokmetije, ki oskrbuje šolo; } \\
\text { - teoretična priprava v šoli; } \\
\text { - kostanjev piknik. } \\
\text { 9. Ekskurzija: } \\
\text { - ogled sušilnice sadja; } \\
\text { - obisk čebelarja; } \\
\text { - obisk torklje (Tonina hiša). } \\
\text { 9. Pouk (medpredmetne povezave): } \\
\text { - kmetijstvo (9. razred OŠ); } \\
\text { - družba; } \\
\text { - BIO, GEO, GOS, TVZ, SPH RU; } \\
\text { - pogovori na temo (osveščanje). } \\
\text { 10. Projekti (zdrava šola) } \\
\text { - Shema sadja; } \\
\text { - Priprava zdrave hrane } \\
\text { 11. Popis domačega hladilnika: } \\
\text { - (Namen: ugotoviti, koliko hrane prihaja iz lokalnega tržišča); } \\
\text { - Kot nadgradnja le tega: narediti nov seznam predlogov-katero živilo bi lahko } \\
\quad \text { nadomestili z lokalnim (domačim). } \\
\text { 12. Sestavi jedilnik za en teden, pri čemer pazi, da pri vsakem obroku vključiš najmanj eno } \\
\text { živilo, ki prihaja z lokalnega trga. }\end{array}$ \\
\hline Srednja šola & $\begin{array}{l}\text { 1. Družbenogeografska vaja (matura) } \\
\text { - obisk ekotržnice (iskanje izvora hrane). } \\
\text { 2. Medpredmetno povezovanje } \\
\text { - biologija (biodiverziteta); } \\
\text { - kemija (prst, onesnaževanje okolja). } \\
\text { 3. Ogled filma } \\
\text { - Hrana d.o.o. (Food, Inc.) } \\
\text { - Kruh naš vsakdanjik } \\
\text { - Projekt: Filmska vzgoja } \\
\text { - Mi hranimo svet (We feed the world) } \\
\text { - Korporacija (The Corporation) } \\
\text { 4. Degustacije ekohrane na ekskurzijah } \\
\text { 5. Delitevjabolk na svetovni dan hrane } \\
\text { 6. Projektni dan (v katerega so vključene vse podteme) } \\
\text { 7. Projektno delo: KRUH } \\
\text { - Medpredmetno povezovanje: likovna vzgoja (risanje, slikanje), glasba } \\
\text { (običaji, pesmi), slovenščina (dela o kruhu), jeziki (pojmi, besede), zgodovina (kruh } \\
\text { skozi zgodovino), geografija. } \\
\text { - Skupni cilij: razvijanje zavedanja o pomenu kruha, razvijanje ustreznega } \\
\text { odnosa do kruha, spoznati nastanek kruha, spoznati običaje, povezane s kruhom. } \\
\text { 8. Pkupna dejavnost: peka kruha. } \\
\text { - Prvi letnik: } \\
\text { 9. Drugi letnik: } \\
\text { - Azija (primerjava s Slovenijo, konkretni, aktualni podatki). }\end{array}$ \\
\hline
\end{tabular}




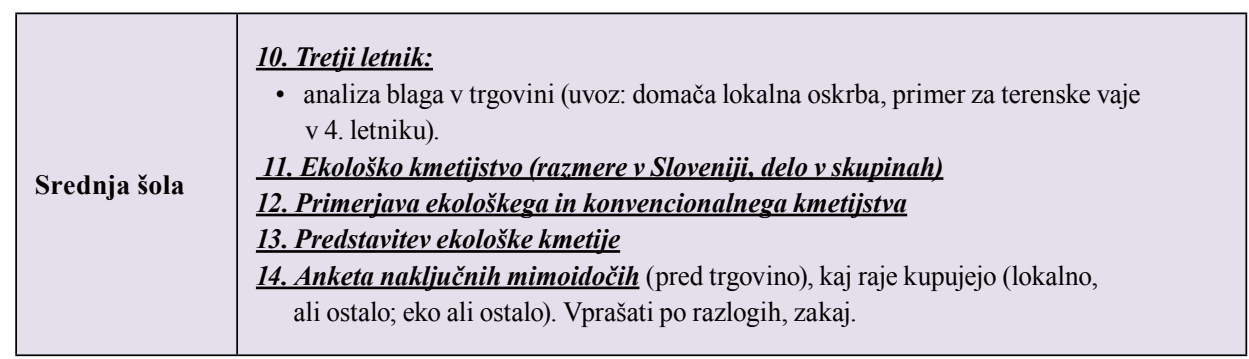

Avtorji/Authors: Udeleženci delavnice na 16. Ilešičevih dnevih septembra 2010.

Štirje primeri nalog, ki so podani v nadaljevanju, so delno povzeti iz priročnika Razmišljamo in delujemo trajnostno, katerega soavtorica je avtorica tega prispevka.

\section{Predlogi nalog}

\section{1. naloga: Kako zdrav je tvoj življenjski slog?}

\section{Praktični napotki za učitelje}

Preglednica 5: Praktični napotki za učitelje

Table 5: Practical suggestions for teachers

\begin{tabular}{|c|c|}
\hline Kaj? & Zdrav življenjski slog \\
\hline Zakaj? & $\begin{array}{l}\text { Učenec/dijak: } \\
\text { - pozna in razume pozitiven pomen zdravega življenjskega sloga posameznika; } \\
\text { - pozna in razume vzroke in posledice nezdravega življenjskega sloga; } \\
\text { - pozna in razume dejavnike zdravega življenjskega sloga ter jih zna kritično ovrednotiti; } \\
\text { - začne morda razmišljati o pozitivni spremembi svojega življenjskega sloga. }\end{array}$ \\
\hline $\begin{array}{l}\text { Pod katerimi } \\
\text { pogoji? }\end{array}$ & $\begin{array}{l}\text { Časovni okvir: } 45 \text { minut (kompleksna, celostna obravnava). } \\
\text { Prostorski okvir: razred. } \\
\text { Udeleženci: učitelj in učenci/dijaki. } \\
\text { Učila in učni pripomočki: slika - zdrav življenjski slog, preglednica. }\end{array}$ \\
\hline Kako? & $\begin{array}{l}\text { Učitelj po lastni presoji vključi nalogo v šolsko uro. } \\
\text { Učitelj lahko za vrednotenje posameznih dejavnikov izbere skupinsko delo ali delo v dvojicah- } \\
\text { vsaka skupina ali dvojica ovrednoti en dejavnik, sledi poročanje in razprava. }\end{array}$ \\
\hline Rezultati & Razmislek, razprava, kvantitativna in kvalitativna analiza. \\
\hline
\end{tabular}

- Oglej si sliko (slika 2), ki prikazuje dejavnike zdravega življenjskega sloga. V spodnji preglednici (preglednica 6) s številkami od 0 (nepomemben) do 5 (zelo pomemben) ovrednoti, koliko tebi osebno pomeni posamezen dejavnik. V tretjem stolpcu razloži, kako sam razumeš posamezen dejavnik. 
Slika 2: Zdrav življenjski slog

Figure 2: Healthy life style

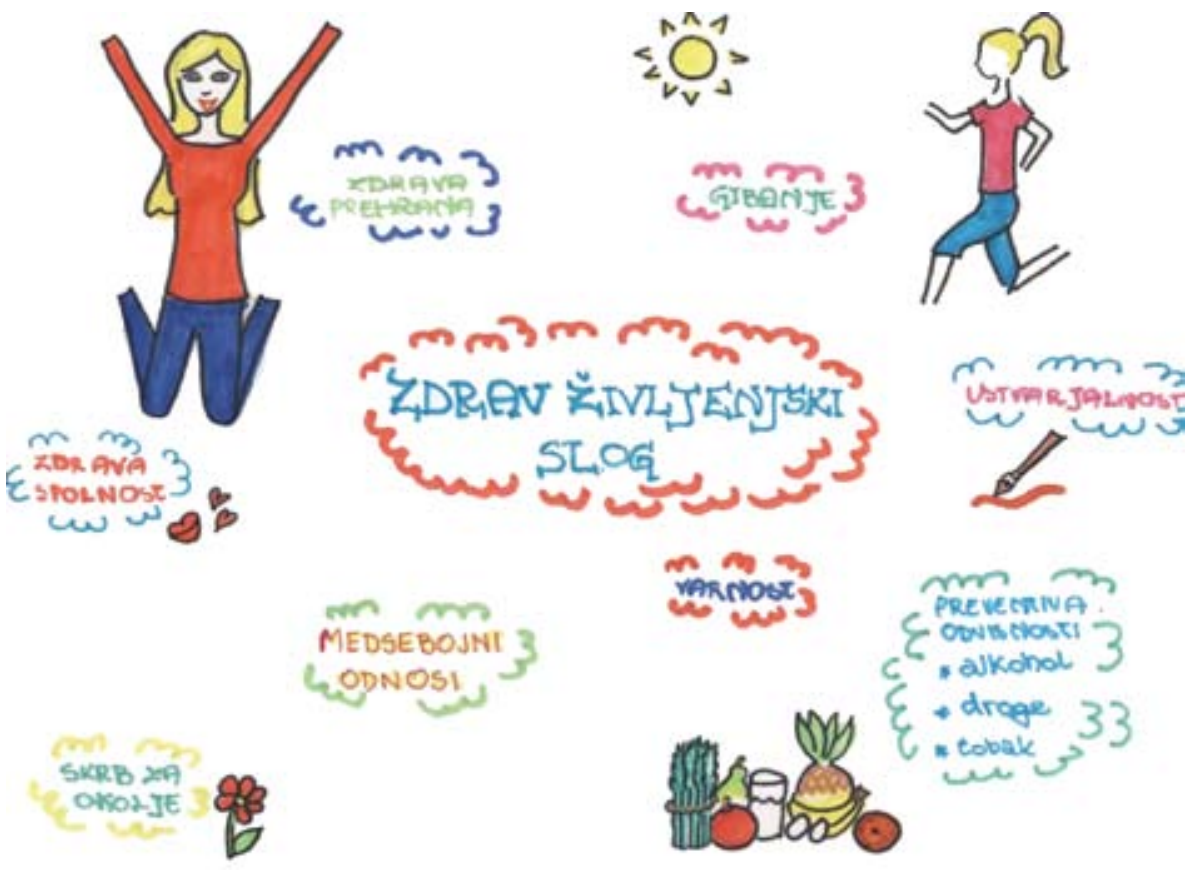

Avtor/Author: M. Planinc 2010

Preglednica 6: Vrednotenje lastnega življenjskega sloga

Table 6: Evaluation of your own life style

\begin{tabular}{|l|l|l|}
\hline DEJAVNIK & $\begin{array}{c}\text { OCENA POMENA } \\
\text { DEJAVNIKA }\end{array}$ & $\begin{array}{c}\text { KAKO SAM/A RAZUMEM } \\
\text { POSAMEZEN DEJAVNIK? }\end{array}$ \\
\hline Zdrava prehrana & & \\
\hline Gibanje & & \\
\hline Medosebni odnosi & & \\
\hline Zdrava spolnost & & \\
\hline Varnost & & \\
\hline Preventiva odvisnosti - alkohol, droge, tobak & & \\
\hline Ustvarjalnost & & \\
\hline Skrb za okolje & & \\
\hline Osebna higiena & & \\
\hline
\end{tabular}


- Na osnovi rezultatov, ki ste jih pridobili s pomočjo preglednice 6, naredite kvantitativno analizo življenjskega sloga v svojem razredu ter kvalitativno analizo na podlagi razprave v okviru fokusnih skupin. V skupine se razdelite s pomočjo žreba.

\section{2. naloga: Ovrednoti izpis iz RESOLUCIJE O NACIONALNEM PROGRAMU PREHRANSKE POLITIKE 2005 - 2010 (ReNPPP)/priporočeno delo v skupinah.}

\section{Praktični napotki za učitelje}

Preglednica 7: Praktični napotki za učitelje

Table 7: Practical suggestions for teachers

\begin{tabular}{|c|c|}
\hline Kaj? & Prehranska politika \\
\hline Zakaj? & $\begin{array}{l}\text { Učenec/dijak: } \\
\text { - pozna in razume pomen ustrezne prehranske politike; } \\
\text { - pozna in razume vzroke in posledice neustrezne prehrane; } \\
\text { - razmišlja o lastnem odnosu do prehrane; } \\
\text { - se uči brati in razumeti strokovna besedila; } \\
\text { - začne morda razmišljati o pozitivni spremembi svojega življenjskega sloga. }\end{array}$ \\
\hline $\begin{array}{l}\text { Pod katerimi } \\
\text { pogoji? }\end{array}$ & $\begin{array}{l}\text { Časovni okvir: } 45 \text { minut (kompleksna, celostna obravnava). } \\
\text { Prostorski okvir: razred. } \\
\text { Udeleženci: učitelj in učenci/dijaki. } \\
\text { Učila in učni pripomočki: izpis iz Resolucije o nacionalnem programu prehranske } \\
\text { politike } 2005-2010 \text {. }\end{array}$ \\
\hline Rezultati & Razmislek, razprava. \\
\hline
\end{tabular}

- Nezdravo prehranjevanje in nezadostna telesna dejavnost sta dejavnika nezdravega življenjskega sloga, h kateremu prispevata tudi kajenje in ǔ̆ivanje alkoholnih pijač.

- Ocene Svetovne zdravstvene organizacije (v nadaljevanjem besedilu: SZO) za leto 2002 kažejo, da so bile $v$ Evropi kronične nenalezljive bolezni (KNB) v $86 \%$ vzrok vseh smrti in v $77 \%$ vzrok vseh bolezni. Tudi $v$ Republiki Sloveniji je več kot 70 \% smrti posledica najpogostejših KNB.

- V Sloveniji število dnevnih obrokov in ritem prehranjevanja povprečnega prebivalca nista ustrezna, energijska vrednost povprečnega obroka je previsoka, zaužijemo preveč maščob v celoti in preveč nasičenih maščob, ki pomembno vplivajo na pojavnost bolezni srca in ožilja in raka širokega črevesa. Zdravo in pretežno zdravo se prehranjuje samo $22,9 \%$ prebivalstva.

- Podatki o zdravstveni ustreznosti živil, zbrani na osnovi rednega programiranega uradnega nadzora nad živili v javnih zdravstvenih ustanovah in na osnovi prijavljenih alimentarnih epidemij kažejo, da kot najpogostejši vzrok zdravstvene neustreznosti živil v Republiki Sloveniji prevladuje mikrobiološka onesnaženost živil, medtem ko prekomerna kemična onesnaženost zaenkrat še ne predstavlja večjega zdravstvenega problema.

- Za ohranjanje in krepitev zdravja je zelo pomembno razmerje med energijskim vnosom in energijsko porabo, skratka med prehranjevanjem in telesno dejavnostjo. Zdrava prehrana in redna telesna dejavnost vplivata na zdravje vsaka zase in hkrati sinergijsko.

- V naši drăavi je skoraj 60 \% odraslih prebivalcev športno neaktivnih, slaba četrtina občasno aktivnih in precej manj kot petina redno, vsaj dvakrat tedensko aktivnih.

- Zdrav življenjski slog omogoča ohranjanje in krepitev zdravja ter kakovosti življenja vsakega posameznika in zmanjšuje družbene stroške preprečevanja in zdravljenja KNB, invalidnosti in prezgodnje smrtnosti. 
Preberi si več v: Nacionalni program prehranske politike za obdobje 2005 do 2010.

\section{3. naloga: En teden si zapisuj, kaj ješ (preglednica 9). Dobljene rezultate primerjaj s} priporočeno prehrambeno piramido in jih ovrednoti. Kaj bi moral spremeniti $v$ svojem načinu prehranjevanja?

\section{Praktični napotki za učitelje}

Preglednica 8: Praktični napotki za učitelje

Table 8: Practical suggestions for teachers

\begin{tabular}{|l|l|}
\hline Kaj? & Moja prehrana \\
\hline \multirow{2}{*}{ Zakaj? } & $\begin{array}{l}\text { Učenec/dijak: } \\
\text { - pozna in razume pomen vsakodnevnega prizadevanja za ustrezno prehranjevanje; } \\
\text { - pozna in razume vzroke in posledice neustrezne prehrane; } \\
\text { razmišlja o lastnem odnosu do prehrane; }\end{array}$ \\
\hline Pod katerimi & $\begin{array}{l}\text { Prostorski okvir: razred. } \\
\text { Udeleženci: učitelj in učenci/dijaki. }\end{array}$ \\
\hline Kako? & $\begin{array}{l}\text { Učila in učni pripomočki: preglednica, prehrambena piramida, tabela kalorične vrednosti } \\
\text { živil. }\end{array}$ \\
\hline Rezultati & Učitelj po lastni presoji vključi nalogo v šolsko uro. \\
\hline
\end{tabular}

Preglednica 9: Moja tedenska prehrana

Table 9: My weekly food

\begin{tabular}{|l|l|l|l|l|l|l|l|}
\hline & Ponedeljek & Torek & Sreda & Četrtek & Petek & Sobota & Nedelja \\
\hline Zajtrk & & & & & & & \\
\hline Malica & & & & & & & \\
\hline Kosilo & & & & & & & \\
\hline Malica & & & & & & & \\
\hline Večerja & & & & & & & \\
\hline Vmesni prigrizki & & & & & & & \\
\hline
\end{tabular}

Izpolni preglednico 9. S pomočjo preglednice kaloričnih vrednosti živil si nato izračunaj, koliko kalorij dnevno vneseš v svoj organizem. Dnevna poraba pri fizični neaktivnosti naj bi bila nekje okrog 1800 kcal za ženske in 2000 kcal za moške. Se tvoj vnos giba v priporočenih okvirih?

- Razdelite se v pare. Vsak par naj sestavi primer kvalitetnega celodnevnega jedilnika (5 obrokov). 


\section{4. naloga: Metoda za in proti: zdrava prehrana / hitra prehrana}

\section{Praktični napotki za učitelje}

Preglednica 10: Praktični napotki za učitelje

Table 10: Practical suggestions for teachers

\begin{tabular}{|c|c|}
\hline Kaj? & Šolska prehrana \\
\hline Zakaj? & $\begin{array}{l}\text { Učenec/dijak: } \\
\text { - pozna in razume pomen vsakodnevnega prizadevanja za ustrezno prehranjevanje; } \\
\text { - pozna in razume vzroke in posledice neustrezne prehrane; } \\
\text { - razmišlja o lastnem odnosu do prehrane; } \\
\text { - začne morda razmišljati o pozitivni spremembi svojega načina prehranjevanja. }\end{array}$ \\
\hline $\begin{array}{l}\text { Pod katerimi } \\
\text { pogoji? }\end{array}$ & $\begin{array}{l}\text { Časovni okvir: } 45 \text { minut (kompleksna, celostna obravnava). } \\
\text { Prostorski okvir: razred. } \\
\text { Udeleženci: učitelj in učenci/dijaki. } \\
\text { Učila in učni pripomočki:dejanski primer enotedenskega šolskega jedilnika, prehrambna } \\
\text { piramida, tabela kalorične vrednosti živil, vprašanja. }\end{array}$ \\
\hline Kako? & $\begin{array}{l}\text { Učitelj po lastni presoji vključi nalogo v šolsko uro. } \\
\text { Učence/dijake lahko razdeli v skupine. Polovica skupin išče argumente za uvedbo zdrave } \\
\text { prehrane v šolske jedilnike, polovica skupin se nagiba k hitri prehrani. Nato se soočijo } \\
\text { po predstavnikih posameznih skupin. Čigavi argumenti so tehtnejši in zakaj? Izhajajoč } \\
\text { iz rezultatov razprave učenci/dijaki ovrednotijo pomen 'primera dobre prakse' - toplega } \\
\text { obroka za dijake. }\end{array}$ \\
\hline Rezultati & $\begin{array}{l}\text { Delo v skupinah, metoda za in proti, primer dobre prakse, razmislek, razprava; } 3 \text {-dnevni } \\
\text { jedilnik šolske prehrane. }\end{array}$ \\
\hline
\end{tabular}

\section{Slika 3: Hitra prehrana/zdrava prehrana}

Figure 3: Healthy food/fast food
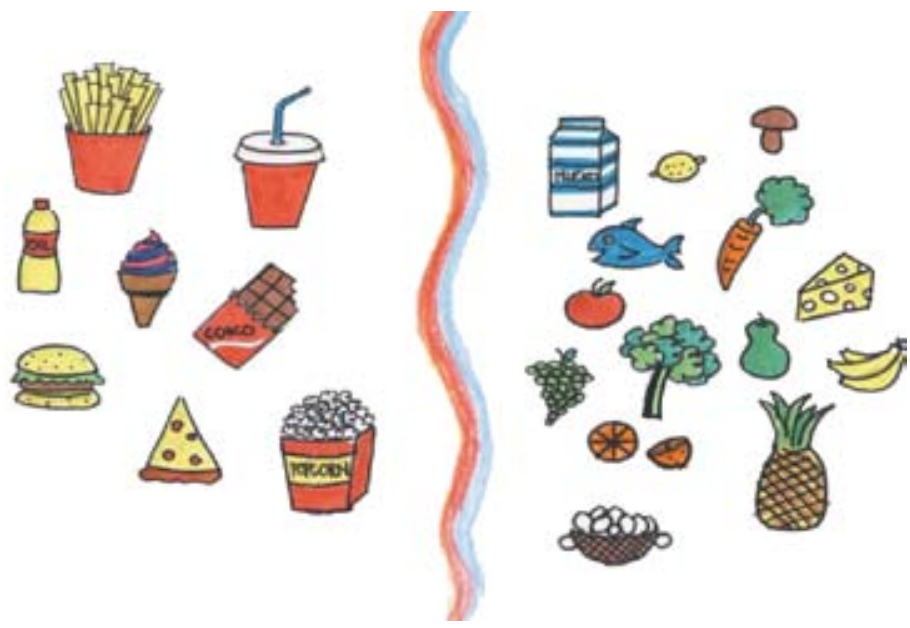

Avtor/Author: M. Planinc 2010 
- V vaši šoli imate možnost vplivati na izbor jedilnikov. Nekateri učenci/dijaki si želijo le t.i. hitre hrane, drugi pa bi raje imeli več zdrave hrane.

- Kateri argumenti vas bodo prepričali?

- Kaj menite o brezplačnem toplem obroku za dijake?

- Katere so dobre in katere slabe strani takega načina prehranjevanja in samega izbora hrane? Kaj bi želeli spremeniti oziroma izboljšati?

- Naredite 3-dnevni jedilnik šolske prehrane. Utemeljite svoj izbor.

\section{SKLEP}

Stofferahn in Goreham (2004) sta identificirala potrošniške trende, ki zagotavljajo možnosti za nadaljnji razvoj lokalno pridelane hrane. Ti trendi vključujejo porast zavedanja o varni hrani, spreminjanje dojemanja organske hrane, spremembe nakupovalnih vzorcev, pripravljenost plačati več za boljše proizvode, porast skrbi za zdravje, povečan delež nakupa sezonskih pridelkov, povečano skrb za kvaliteto življenja ter zavedanje pomena podpiranja lokalnega gospodarstva. Vendar obstajajo veliki razkoraki v komunikaciji in razumevanju delovanja sistema lokalne oskrbe s hrano med laično javnostjo, mediji ter proizvajalci hrane. Samo želimo si lahko, da bi učitelji (in z njimi celoten sistem izobraževanja) prepoznali raznolikost dojemanj lokalne trajnostne oskrbe s hrano ter skušali o problematiki ozavestiti otroke in mladino.

Po Wheelerju (2004) so strategije izobraževanja, komunikacije in usklajevanja med najpomembnejši orodji za doseganje dolgoročnih sprememb, saj je skupni imenovalec teh strategij spoznanje, da je predpogoj političnih ali družbenih sprememb sprememba prepričanj, znanj, vrednot in paradigem razmišljanja ljudi. Takšno razumevanje lahko vodi v široko paleto izobraževalnih aktivnosti. Rezultati dveh raziskav (Resnik Planinc 2006; 2008), ki sta potekali v sklopu projekta R.A.V.E. Space (Raising Awareness of Values of Space), so potrdili velik pomen sodelovanja in vključevanja javnosti za delovanje učiteljev, pri čemer pa se moramo ves čas zavedati, da je ljudi potrebno ustrezno izobraziti, če želimo, da bodo razumeli kompleksnost lokalne oskrbe s hrano in poznali možnosti lastne aktivne udeležbe.

Ideja, da je potrebno o lokalni trajnostni oskrbi s hrano čim bolje poučiti že otroke v šoli, je nekako samoumevna. Šola nas uči življenjsko pomembnih vsebin in veščin, zato se vse, kar dobi težo splošno potrebnega znanja, umešča $v$ šolske programe. Umestitev katerekoli teme v obvezni izobraževalni program je svojstven dokaz njenega pomena za vsakdanje življenje in razvoj posameznika in družbe ter zagotovilo, da bodo sporočila dosegla najširši krog prebivalstva. Obstaja upanje, da bodo rezultati vidni kmalu, saj učinki novega znanja skozi šolski sistem dosežejo poleg učencev tudi učitelje, starše in druge odrasle.

Če se vrnemo k vprašanju, kaj torej prinaša učenje o lokalni trajnostni oskrbi s hrano v šolo, nam pregled mednarodnih praks pokaže, da se učenje o tem vključuje v programe na vse naslednje načine (Fridl in sod. 2007):

- prek učnih načrtov;

- z novimi znanji, učili in učnimi pripomočki za učitelje;

- s selitvijo pouka v odprt prostor ob šoli in tudi v lokalno okolje; 
- z vključevanjem zunanjih strokovnih sodelavcev;

- $\mathrm{z}$ izvajanjem različnih dopolnilnih programov.

Le tako bomo ustvarjali stimulativnejše okolje in kvalitetnejšo osnovo za nadaljnji napredek otroka oziroma mladostnika, kar pa je seveda eden naših najpomembnejših ciljev.

\section{Viri in literatura}

Buzeti, T. 2005: Od njive do krožnika z lokalno trajnostno oskrbo. Center za zdravje in razvoj. Murska Sobota.

Cunder, K., Hajdinjak, B., Kandrič, B., Kürbus, T. 2001: Obča geografija za 1. letnik gimnazij. Mladinska knjiga, 152 str. Ljubljana.

Dahlberg, K. A. 1994: Localizing food systems. The Neighbourhood Works, 14 str.

DeLind, L. 1994: Local foods: There's no place like home. Groundwork, str. 4-5.

Fridl, J., Kušar, S., Resnik Planinc, T., Simoneti, M. 2007: Vključevanje vrednot prostora $\mathrm{v}$ proces izobraževanja. V: Kurikul kot proces in razvoj. Zbornik prispevkov posveta $\mathrm{v}$ Postojni januarja 2007. Zavod RS za šolstvo, str. 195-209. Ljubljana.

Gabrijelčič Blenkuš M., Gregorič, M., Tivadar, B., Koch, V., Kostanjevec, S., Fajdiga Turk, V., Žalar, A., Lavtar, D., Kuhar, D., Rozman, U. 2009: Prehrambene navade odraslih prebivalcev Slovenije z vidika varovanja zdravja, 183 str. Ljubljana.

Gordon, S. 2003: Local food challenge announcement. Medmrežje: http://www.mail-archive. com/community_garden@list.communitygarden.org/msg01420.html (10.9. 2010).

Klemenc, A., Resnik Planinc, T., Urbanc, M., Vičar Potočnik, H., Blejec, M., Dintinjana, T., Škapin, D. 2010: Razmišljamo in delujemo trajnostno. Priročnik za vključevanje vsebin trajnostnega razvoja v izobraževanje. Medmrežje: http://www.cpi.si/mednarodno-sodelovanje/ess/kakovost-in-prepoznavnost/zakladnica-znanja/trajnostni-razvoj.aspx (10. 10. 2010).

Kunaver, J., Lovrenčak, F., Senegačnik, J., Drobnjak, B., Pak, M., Klemenčič, M., Luževič, M. 2004: Geografija za srednje šole, DZS, 285 str. Ljubljana.

Nacionalni program prehranske politike 2005-2010, 47 str. Ljubljana 2005.

Novak, F. 2003: Geografija Slovenije. Učbenik za 9. razred devetletne in 8. razred osemletne osnovne šole. DZS, 112 str. Ljubljana.

Stofferahn, C., Goreham, G. (n. d.): Sustainable community food systems: Case studies. Medmrežje: http://www.und.edu/misc/ndrural/Case\%20Studies.pdf (15. 9. 2010).

Račič, J., Večerič, D. 2006: Geografija 9. Učbenik za geografijo v devetem razredu osnovne šole. Mladinska knjiga, 91 str. Ljubljana.

Resnik Planinc, T. 2006: Vrednote prostora kot integralni del izobraževanja. Geografski vestnik 78, 2, str. 9-24. Ljubljana.

Resnik Planinc, T. 2008: Geographical education and values of space: a comparative assessment from five European countries. International research in geographical and environmental education 17, 1, str. 56-73. Bundoora.

Senegačnik, J., Drobnjak, B. 2002: Obča geografija za 1. letnik gimnazij. Modrijan, 183 str. Ljubljana. 
Senegačnik, J., Drobnjak, B., Otič, M. 2008: Živim v Sloveniji. Geografija za 9. razred osnovne šole. Modrijan, 151 str. Ljubljana.

Senegačnik, J. 2008: Slovenija 1. Modrijan, 120 str. Ljubljana.

Slovenija preveč hrane uvaža. Medmrežje: http://www.tvslovenija.si/slovenija/slovenija-prevec-hrane-uvaza/215390 (15. 10. 2010).

Thomson, J. S., Radhakrishna, R. B., Maretzki, A. N., Inciong, L. O. 2006: Strengthening community engagement toward sustainable local food systems. Journal of extension 44, 4, Feature Articles // 4FEA2. Medmrežje: http://www.joe.org/joe/2006august/a2.php (10. 9. 2010)

Učni načrt. Geografija; gimnazija; splošna, klasična, ekonomska. Ministrstvo za šolstvo in šport, Zavod RS za šolstvo. Ljubljana 2008.

Učni načrt. Program osnovnošolskega izobraževanja. Geografija. Ministrstvo za šolstvo in šport, Zavod RS za šolstvo. Ljubljana 2003.

Učni načrt. Geografija: strokovna gimnazija. Ministrstvo za šolstvo in šport, Zavod RS za šolstvo. Ljubljana 2008.

Wheeler, S. M. 2004: Planning for sustainability. Creating liveable, equitable, and ecological communities. Routledge, 280 str. London.

\section{EDUCATION FOR LOCAL SUSTAINABLE FOOD SUPPLY}

\section{Summary}

Local sustainable food supply is one of the strategic objectives of nutrition policy, as defined in the Resolution on national nutrition policy 2005-2010. Although we are all aware of its importance, the theory passes slowly into practice, which in turn means that in education and awareness building in children and adolescents, much remains to be done.

Since we all have to eat, food is in itself an excellent starting point for education, because it is important what we eat. Our food choice affects our health, environmental quality, jobs in our communities, culture and diversity in our society. It is not enough to just provide a supply of healthy, preferably locally grown food in restaurants, tourist establishments and in public institutions, which include nurseries, schools and other educational institutions and student accommodation.

Simply informing and advising is also not enough. We expect people to change their lifestyle and diet, but even for an adult this is sometimes extremely difficult, let alone for a child or adolescent. These changes must start in their primary cells - their families. If the child or adolescent feels and understands that this is something good, something that their family, school and society at large supports, he or she will be willing to accept change more rapidly than if they are just taught the facts at a formal and theoretical level in school.

Air pollution, food additives, antibiotics, animal welfare, biodiversity, climate change, cloning, pesticides, mad cow disease, health, genetic engineering, organic food, poverty and famine, etc. are only some topics with which youth is faced nowadays. If we want them to understand their complexities, importance and influence, we must be exceptionally professional, precise and consistent in the planning of our educational work. 
At the same time, the public must be aware that teachers are committed to the set curriculum, in which (even in revised examples) the content relating to sustainable local food supply is either not included, or if it is, not to a sufficient extent. It is certainly difficult to talk about the priority of a single school subject that could cover the comprehensiveness of these pressing issues, so cross-curricular integration is one way to achieve this.

The current Slovenian syllabi for geography do not refer to local sustainable food supply specifically in any of the learning objectives, although some general learning objectives allow the teacher to include this complex subject in the teaching process. We must be aware, however, that it is the teacher's own awareness and understanding of the topic that allows this to happen.

The principles of a sustainable local food supply require that we, as individuals and as part of society, think about our own lifestyle, the consequences of our actions in terms of development, social progress and the environmental situation and then form appropriate solutions. Besides thinking about making a better life for ourselves, we should also consider the possibilities and opportunities for future generations.

Implementing innovations in school is certainly one of the most demanding tasks. Education about sustainable dimensions in life and development should shift away from just information giving toward looking at processes, relationships and attitudes, what requires cognitive and project learning and cross-curricular integration. Methodologically, these expectations match the development of teaching itself, which is certainly in favor of the topic. The theme itself however, suggests many possibilities for the practical acquisition of knowledge, while at the same time in every school or group the topic can take on a completely unique dimension. Each task is being developed and connected by people, space and problems. The teachers have had to face a difficult task, but this also means that they have acquired new and different experiences.

The idea that children and young people need to be educated about local sustainable food supply in school is somehow self-evident. Since school teaches us about life-relevant skills, any subject that communicates theses necessary skills should be placed in school curricula. The placement of any issue into compulsory education programmes is evidence of its unique importance in everyday life. It leads towards the development of an individual and society and ensuring that messages reach the widest circle of people.

The review of international practices suggests that learning about local sustainable food supply in schools, can be implemented in many ways (Fridl et all 2007):

- through the curricula;

- with new knowledge, learning and teaching aids for teachers;

- through the relocation of classes into an open space in the school or the local environment;

- through the involvement of external experts;

- through the implementation of a variety of complementary programmes.

Only then we will create the environment of higher quality and stimulation that will lead towards further progress of child or adolescent, which is one of our most important goals. 